\title{
Mini-Review
}

\section{Axial Level-Specific Regulation of Neuronal Development: Lessons From PITX2}

\author{
Mindy R. Waite ${ }^{1}$ and Donna M. Martin ${ }^{1,2,3}{ }^{\star}$ \\ ${ }^{1}$ Cellular and Molecular Biology Graduate Program, University of Michigan, Ann Arbor, Michigan \\ ${ }^{2}$ Department of Pediatrics, University of Michigan, Ann Arbor, Michigan \\ ${ }^{3}$ Department of Human Genetics, University of Michigan, Ann Arbor, Michigan
}

Transcriptional regulation of gene expression is vital for proper control of proliferation, migration, differentiation, and survival of developing neurons. Pitx2 encodes a homeodomain transcription factor that is highly expressed in the developing and adult mammalian brain. In humans, mutations in PITX2 result in Rieger syndrome, characterized by defects in the development of the eyes, umbilicus, and teeth and variable abnormalities in the brain, including hydrocephalus and cerebellar hypoplasia. Alternative splicing of Pitx2 in the mouse results in three isoforms, Pitx2a, Pitx2b, and Pitx2c, each of which is expressed symmetrically along the left-right axis of the brain throughout development. Here, we review recent evidence for axial and brain region-specific requirements for Pitx2 during neuronal migration and differentiation, highlighting known isoform contributions. (c) 2014 Wiley Periodicals, Inc.

Key words: brain; migration; differentiation; spinal cord

In humans, heterozygosity for mutations in the homeodomain transcription factor gene PITX2 results in Rieger syndrome, characterized by ocular defects, dental malformations/hypodontia, craniofacial abnormalities, and failure of periumbilical involution (Semina et al., 1996). Some individuals with Rieger syndrome have structural brain defects that include cerebellar hypoplasia, enlargement of the cisterna magna, and hydrocephalus, but the underlying mechanisms contributing to these defects are not known (Idrees et al., 2006). In humans, PITX2 is expressed as four distinct isoforms, PITX2A, PITX2B, PITX2C, and PITX2D, through alternative splicing and promoter usage (Cox et al., 2002); however, the specific expression patterns of each isoform in the human brain have not been fully explored.

In mice, Pitx 2 has a broad range of expression and is required for development of the eyes, teeth, heart, lungs, gut, umbilicus, and central nervous system (CNS; Ryan et al., 1998; Gage et al., 1999; Kitamura et al., 1999; Lin et al., 1999; Hjalt et al., 2000; Suh et al., 2002; Martin et al., 2004). In the CNS, Pitx2 is expressed in the forebrain (subthalamic nucleus, mammillary region, and zona limitans intrathalamica), midbrain (superior colliculus and red nucleus), hindbrain (ventral rhombomere 1), and spinal cord (Fig. 1; Mucchielli et al., 1997; Lindberg et al., 1998; Martin et al., 2002; Zagoraiou et al., 2009; Waite et al., 2011, 2012; Matsui et al., 2013). Pitx2 is expressed in mice as three distinct isoforms, Pitx2a, Pitx2b, and Pitx 2c. In the mouse, all three isoforms are expressed in the developing craniofacial tissue, brain, hematopoietic stem cells in the liver, pituitary, eyes, and teeth (Gage and Camper; 1997; Smidt et al., 2000; C. Liu et al., 2001; W. Liu et al., 2003; Kieusseian et al., 2006; Ai et al., 2007; Waite et al., 2013), whereas only Pitx2c is expressed in the lateral plate mesoderm, heart, lungs, and gut (Kitamura et al., 1999; Schweickert et al., 2000; Yu et al., 2001).

All three isoforms are present by E9.25-E9.5 in the developing brain (Gage and Camper, 1997; Smidt et al., 2000; C. Liu et al., 2001; W. Liu et al., 2003; Kieusseian et al., 2006; Ai et al., 2007; Waite et al., 2011). In the developing zebrafish brain, Pitx $2 c$ is expressed asymmetrically, and Pitx $2 a$ and Pitx $2 b$ are not present (Essner et al., 2000), suggesting that the requirements and roles for Pitx2 isoforms are species specific.

\section{PROLIFERATION AND MIGRATION}

Pitx2 is expressed primarily in postmitotic neurons (Smidt et al., 2000; Martin et al., 2002) and has no known role in neural progenitor proliferation. Global and neural-specific loss of Pitx 2 results in arrested or delayed migration of

Contract grant sponsor: NIH, Contract grant number: R01 NS054784 (to D.M.M.)

${ }^{\star}$ Correspondence to: Donna M. Martin, MD, PhD, 3520A Medical Science Research Building I, University of Michigan Medical Center, Ann Arbor, MI 48109-5652. E-mail: donnamm@umich.edu

Received 21 April 2014; Revised 9 June 2014; Accepted 16 July 2014

Published online 14 August 2014 in Wiley Online Library (wileyonlinelibrary.com). DOI: 10.1002/jnr.23471 

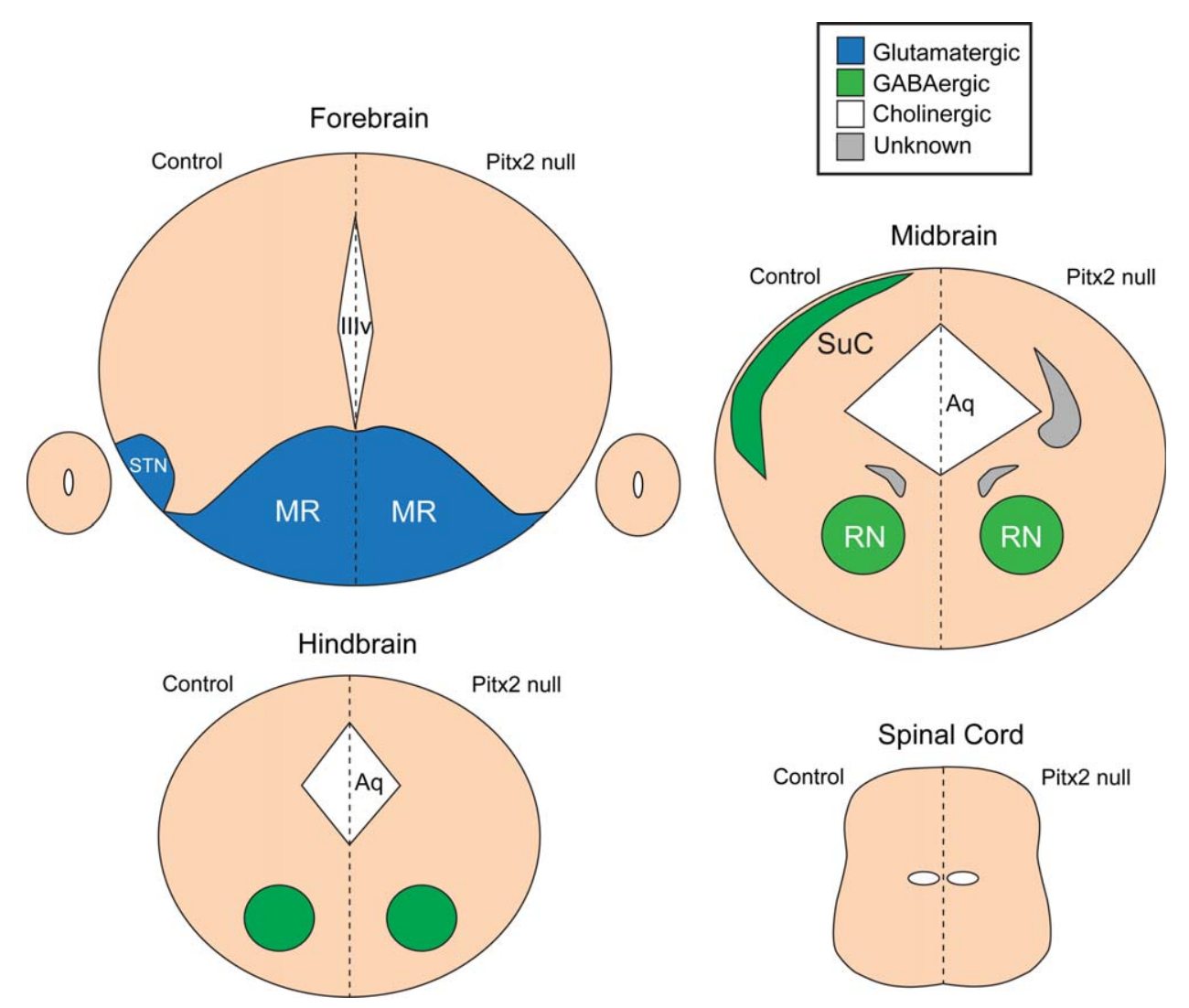

Fig. 1. Pitx2 expression throughout the brain and spinal cord and effects of loss of Pitx2 on various neuronal populations. Schematic of Pitx 2 expression in coronal sections of the forebrain, midbrain, hindbrain, and spinal cord. Left side of the coronal section represents control genotype, and right side represents the Pitx2 null genotype. Pitx2-positive populations are color coded based on their neurotransmitter identity. IIIv, third ventricle; Aq, aqueduct; MR, mammillary region; RN, red nucleus; SuC, superior colliculus; STN, subthalamic nucleus.

neurons in the subthalamic nucleus and midbrain in a cell-autonomous manner (Martin et al., 2004; Skidmore et al., 2008; Waite et al., 2011). Effects of Pitx2 deficiency on migration have not been observed at other axial levels, and it is not known whether Pitx2 regulates proliferation or neuronal migration in other brain regions.

\section{GABAergic DIFFERENTIATION}

In the dorsal midbrain, Pitx2 is required for the development of GABAergic neurons via a molecular cascade that begins with Helt, a basic helix-loop-helix (bHLH) transcription factor expressed in, and required for, GABAergic midbrain progenitor neuronal differentiation (Cazorla et al., 2000; Miyoshi et al., 2004; Nakatani et al., 2004). Helt cooperates with Ascl1 to promote GABAergic differentiation, and Helt is required for expression of the transcription factor Gata2 in neural progenitors as they exit the cell cycle (Kala et al., 2009). In turn, Gata2 is required in neuronal GABAergic precursors to promote GABAergic over glutamatergic fates and for downstream Pitx2 expression. Pitx2 null mice exhibit loss of GABA in mid- brain Pitx2-expressing neurons, suggesting that Pitx2 is required for GABAergic differentiation of a midbrain neuronal subpopulation (Waite et al., 2011). Finally, Pitx2 is known to activate the Gad1 promoter (Westmoreland et al., 2001) and might therefore function as a GABAergic terminal differentiation factor in the midbrain Helt cascade.

Although Pitx2 appears to be required for the differentiation of some GABAergic subpopulations, little is known about human diseases resulting from GABAergic neuron loss in these regions. Additionally, genes required for GABAergic subpopulation differentiation, such as Ascl1, Helt, and Gata2, are critical for mouse survival, and detailed studies of conditional deletions are required to determine the downstream impact of GABAergic neuronal loss (Guillemot et al., 1993; Tsai et al., 1994; Guimera et al., 2006). Mice lacking Helt die at 5 weeks old, possibly as a result of neurological impairment, suggesting that the loss of specific GABAergic subpopulations might be fatal. Studies of fetal valproate syndrome suggest that early loss of specific GABAergic subpopulations in the superior colliculus might result in decreased startle responses and 
prepulse inhibition as well as increased sensitivity to nociception (Dendrinos et al., 2011). Future studies will identify additional functional roles for specific Pitx2expressing GABAergic subpopulations and how they impact behavioral and health disorders.

\section{AXON FORMATION}

In addition to its roles in neural progenitor proliferation, differentiation, and migration, Pitx 2 has been shown to regulate axon formation of the mammillothalamic tract (MTT), an axonal projection that is involved in selfmovement cue processing and spatial memory (Vann and Aggleton, 2003, 2004; Kim et al., 2009; Winter et al., 2011). Normally, the MTT is detectable in mice at E18 as it bifurcates rostrally from the principal mammillary tract (PMT; Valverde et al., 2000; Skidmore et al., 2012). In Nestin-Cre Pitx2 conditional null mice, the PMT appears normal in size and location, whereas the MTT is absent. Because Pitx2 is highly expressed in the mammillary area and in the cells surrounding the MTT, these data suggest a noncell-autonomous requirement for Pitx2 in the establishment of this important neural projection (Skidmore et al., 2012).

\section{NEURONAL SURVIVAL AND MAINTENANCE}

Pitx2 expression persists in the brain from embryonic development through adulthood, suggesting that it might also have important roles in neuronal maintenance or ongoing signaling to neighboring cells, although this has not been formally tested (Smidt et al., 2000). Pitx2 does not appear to be required for cell survival, in that loss of Pitx2 does not promote neuronal death (Martin et al., 2004; Waite et al., 2011). It is not known whether Pitx2 is required for maintenance of mature neuronal identity.

\section{SUMMARY}

In the CNS, Pitx2 is expressed in distinct neuronal populations in the forebrain, midbrain, hindbrain, and spinal cord. Pitx2 is required in an isoform-specific manner for formation of the MTT in the forebrain and migration and differentiation of a midbrain GABAergic subpopulation. The specific requirements for Pitx2 in the hindbrain and spinal cord are still being explored, but early studies point to functions in cellular differentiation and fate establishment. Further characterization of the mechanisms by which Pitx2 functions should lead to improvements in our understanding of axial level-specific contexts that influence neuronal development.

\section{REFERENCES}

Ai D, Wang J, Amen M, Lu MF, Amendt BA, Martin JF. 2007. Nuclear factor 1 and T-cell factor/LEF recognition elements regulate Pitx2 transcription in pituitary development. Mol Cell Biol 27:5765-5775.

Cazorla P, Smidt MP, O’Malley KL, Burbach JP. 2000. A response element for the homeodomain transcription factor Ptx3 in the tyrosine hydroxylase gene promoter. J Neurochem 74:1829-1837.

Cox CJ, Espinoza HM, McWilliams B, Chappell K, Morton L, Hjalt TA, Semina EV, Amendt BA. 2002. Differential regulation of gene expression by PITX2 isoforms. J Biol Chem 277:25001-25010.
Dendrinos G, Hemelt M, Keller A. 2011. Prenatal VPA exposure and changes in sensory processing by the superior colliculus. Front Integr Neurosci 5:68

Essner JJ, Branford WW, Zhang J, Yost HJ. 2000. Mesendoderm and left-right brain, heart, and gut development are differentially regulated by Pitx2 isoforms. Development 127:1081-1093.

Gage PJ, Camper SA. 1997. Pituitary homeobox 2, a novel member of the bicoid-related family of homeobox genes, is a potential regulator of anterior structure formation. Hum Mol Genet 6:457-464.

Gage PJ, Suh H, Camper SA. 1999. Dosage requirement of Pitx2 for development of multiple organs. Development 126:4643-4651.

Guillemot F, Lo LC, Johnson JE, Auerbach A, Anderson DJ, Joyner AL. 1993. Mammalian achaete-scute homolog 1 is required for the early development of olfactory and autonomic neurons. Cell 75:463-476.

Guimera J, Weisenhorn DV, Wurst W. 2006. Megane/Heslike is required for normal GABAergic differentiation in the mouse superior colliculus. Development 133:3847-3857.

Hjalt TA, Semina EV, Amendt BA, Murray JC. 2000. The Pitx2 protein in mouse development. Dev Dyn 218:195-200.

Idrees F, Bloch-Zupan A, Free SL, Vaideanu D, Thompson PJ, Ashley P, Brice G, Rutland P, Bitner-Glindzicz M, Khaw PT, Fraser S, Sisodiya SM, Sowden JC. 2006. A novel homeobox mutation in the PITX2 gene in a family with Axenfeld-Rieger syndrome associated with brain, ocular, and dental phenotypes. Am J Med Genet B Neuropsychiatr Genet 141:184-191.

Kala K, Haugas M, Lillevali K, Guimera J, Wurst W, Salminen M, Partanen J. 2009. Gata2 is a tissue-specific postmitotic selector gene for midbrain GABAergic neurons. Development 136:253-262.

Kieusseian A, Chagraoui J, Kerdudo C, Mangeot PE, Gage PJ, Navarro N, Izac B, Uzan G, Forget BG, Dubart-Kupperschmitt A. 2006. Expression of Pitx2 in stromal cells is required for normal hematopoiesis. Blood 107:492-500.

Kim E, Ku J, Namkoong K, Lee W, Lee KS, Park JY, Lee SY, Kim JJ, Kim SI, Jung YC. 2009. Mammillothalamic functional connectivity and memory function in Wernicke's encephalopathy. Brain 132:369-376.

Kitamura K, Miura H, Miyagawa-Tomita S, Yanazawa M, Katoh-Fukui Y, Suzuki R, Ohuchi H, Suehiro A, Motegi Y, Nakahara Y, Kondo S, Yokoyama M. 1999. Mouse Pitx2 deficiency leads to anomalies of the ventral body wall, heart, extra- and periocular mesoderm, and right pulmonary isomerism. Development 126:5749-5758.

Lin CR, Kioussi C, O'Connell S, Briata P, Szeto D, Liu F, IzpisuaBelmonte JC, Rosenfeld MG. 1999. Pitx2 regulates lung asymmetry, cardiac positioning, and pituitary and tooth morphogenesis. Nature 401:279-282.

Lindberg C, Wunderlich M, Ratliff J, Dinsmore J, Jacoby DB. 1998. Regulated expression of the homeobox gene, $\mathrm{rPtx} 2$, in the developing rat. Brain Res Dev Brain Res 110:215-226.

Liu C, Liu W, Lu MF, Brown NA, Martin JF. 2001. Regulation of left-right asymmetry by thresholds of Pitx2c activity. Development 128:2039-2048.

Liu W, Selever J, Lu MF, Martin JF. 2003. Genetic dissection of Pitx2 in craniofacial development uncovers new functions in branchial arch morphogenesis, late aspects of tooth morphogenesis, and cell migration. Development 130:6375-6385.

Martin DM, Skidmore JM, Fox SE, Gage PJ, Camper SA. 2002. Pitx2 distinguishes subtypes of terminally differentiated neurons in the developing mouse neuroepithelium. Dev Biol 252:84-99.

Martin DM, Skidmore JM, Philips ST, Vieira C, Gage PJ, Condie BG, Raphael Y, Martinez S, Camper SA. 2004. PITX2 is required for normal development of neurons in the mouse subthalamic nucleus and midbrain. Dev Biol 267:93-108.

Matsui T, Hongo Y, Haizuka Y, Kaida K, Matsumura G, Martin DM, Kobayashi Y. 2013. C-terminals in the mouse branchiomotor nuclei originate from the magnocellular reticular formation. Neurosci Lett 548:137-142. 
Miyoshi G, Bessho Y, Yamada S, Kageyama R. 2004. Identification of a novel basic helix-loop-helix gene, Heslike, and its role in GABAergic neurogenesis. J Neurosci 24:3672-3682.

Mucchielli ML, Mitsiadis TA, Raffo S, Brunet JF, Proust JP, Goridis C. 1997. Mouse Otlx2/RIEG expression in the odontogenic epithelium precedes tooth initiation and requires mesenchyme-derived signals for its maintenance. Dev Biol 189:275-284.

Nakatani T, Mizuhara E, Minaki Y, Sakamoto Y, Ono Y. 2004. Helt, a novel basic-helix-loop-helix transcriptional repressor expressed in the developing central nervous system. J Biol Chem 279:16356-16367.

Ryan AK, Blumberg B, Rodriguez-Esteban C, Yonei-Tamura S, Tamura K, Tsukui T, de la Pena J, Sabbagh W, Greenwald J, Choe S, Norris DP, Robertson EJ, Evans RM, Rosenfeld MG, Izpisua Belmonte JC. 1998. Pitx2 determines left-right asymmetry of internal organs in vertebrates. Nature 394:545-551.

Schweickert A, Campione M, Steinbeisser H, Blum M. 2000. Pitx2 isoforms: involvement of Pitx $2 \mathrm{c}$ but not Pitx2a or Pitx $2 b$ in vertebrate left-right asymmetry. Mech Dev 90:41-51.

Semina EV, Reiter R, Leysens NJ, Alward WL, Small KW, Datson NA, Siegel-Bartelt J, Bierke-Nelson D, Bitoun P, Zabel BU, Carey JC, Murray JC. 1996. Cloning and characterization of a novel bicoidrelated homeobox transcription factor gene, RIEG, involved in Rieger syndrome. Nat Genet 14:392-399

Skidmore JM, Cramer JD, Martin JF, Martin DM. 2008. Cre fate mapping reveals lineage specific defects in neuronal migration with loss of Pitx2 function in the developing mouse hypothalamus and subthalamic nucleus. Mol Cell Neurosci 37:696-707.

Skidmore JM, Waite MR, Alvarez-Bolado G, Puelles L, Martin DM. 2012. A novel TaulacZ allele reveals a requirement for Pitx2 in formation of the mammillothalamic tract. Genesis 50:67-73.

Smidt MP, Cox JJ, van Schaick HS, Coolen M, Schepers J, van der Kleij AM, Burbach JP. 2000. Analysis of three Ptx2 splice variants on transcriptional activity and differential expression pattern in the brain. J Neurochem 75:1818-1825.

Suh H, Gage PJ, Drouin J, Camper SA. 2002. Pitx2 is required at multiple stages of pituitary organogenesis: pituitary primordium formation and cell specification. Development 129:329-337.
Tsai FY, Keller G, Kuo FC, Weiss M, Chen J, Rosenblatt M, Alt FW, Orkin SH. 1994. An early haematopoietic defect in mice lacking the transcription factor GATA-2. Nature 371:221-226.

Valverde F, Garcia C, Lopez-Mascaraque L, De Carlos JA. 2000. Development of the mammillothalamic tract in normal and Pax-6 mutant mice. J Comp Neurol 419:485-504.

Vann SD, Aggleton JP. 2003. Evidence of a spatial encoding deficit in rats with lesions of the mammillary bodies or mammillothalamic tract. J Neurosci 23:3506-3514.

Vann SD, Aggleton JP. 2004. The mammillary bodies: two memory systems in one? Nat Rev Neurosci 5:35-44.

Waite MR, Skidmore JM, Billi AC, Martin JF, Martin DM. 2011. GABAergic and glutamatergic identities of developing midbrain Pitx2 neurons. Dev Dyn 240:333-346.

Waite MR, Skaggs K, Kaviany P, Skidmore JM, Causeret F, Martin JF, Martin DM. 2012. Distinct populations of GABAergic neurons in mouse rhombomere 1 express but do not require the homeodomain transcription factor PITX2. Mol Cell Neurosci 49: 32-43.

Waite MR, Skidmore JM, Micucci JA, Shiratori H, Hamada H, Martin JF, Martin DM. 2013. Pleiotropic and isoform-specific functions for Pitx2 in superior colliculus and hypothalamic neuronal development. Mol Cell Neurosci 52:128-139.

Westmoreland JJ, McEwen J, Moore BA, Jin Y, Condie BG. 2001. Conserved function of Caenorhabditis elegans UNC-30 and mouse Pitx2 in controlling GABAergic neuron differentiation. J Neurosci 21:68106819.

Winter SS, Wagner SJ, McMillin JL, Wallace DG. 2011. Mammillothalamic tract lesions disrupt dead reckoning in the rat. Eur J Neurosci 33: 371-381.

Yu X, St Amand TR, Wang S, Li G, Zhang Y, Hu YP, Nguyen L, Qiu MS, Chen YP. 2001. Differential expression and functional analysis of Pitx2 isoforms in regulation of heart looping in the chick. Development 128:1005-1013.

Zagoraiou L, Akay T, Martin JF, Brownstone RM, Jessell TM, Miles GB. 2009. A cluster of cholinergic premotor interneurons modulates mouse locomotor activity. Neuron 64:645-662. 